An Inquiry by Social Workers into Evening Routines in

Community Living Settings for Adults with Learning Disabilities

Elaine James, Mark Harvey, Rob Mitchell

Elaine James, Department of Health Research, Lancaster University

e.james4@lancaster.ac.uk

Mark Harvey, Health \& Community Services, Comnet 54353, AP2107 Ground Floor, Apsley One, Brindley Way, Hemel Hempstead, Hertfordshire, HP3 PBF

mark.harvey@hertfordshire.gov.uk

Rob Mitchell, City of Bradford MDC, Britannia House, Bradford

rob.mitchell@bradford.gov.uk

Correspondence to e.james4@lancaster.ac.uk 


\section{An Inquiry by Social Workers into Evening Routines in Community Living Settings for Adults with Learning Disabilities Abstract}

Significant progress has been made since the 1980s in supporting adults with learning disability to live independent lives in the community. In 2012, the Department of Health in England announced the latest policy initiative to further invest in community support for people with learning disabilities, Transforming Care. Building the right community supported living setting for people does not in isolation provide for a comprehensive strategy towards achieving a paradigm shift in how people with learning disabilities experience their full right to inclusion in their communities.

We undertook a practice inquiry into the quality of life experienced by people with learning disabilities. Social workers chose the focus of the inquiry to be on people's evening routines to answer the question - were people living in the community experiencing independence or did institutional routines define their lives. The findings were that $69 \%$ of people with a learning disability were either in bed or were ready for bed. There was evidence that institutionalised routines existed in the settings with an association between an early evening meal time and the person being ready for or in bed $(p=0.0001$ at Time 1 and $p=0.051$ at Time 2$)$. Implications for social work practice are discussed. 
From the early 1980s the UK has implemented a programme of deinstutionalisation (Emerson \& Hatton 2006) which superficially appears to be achieving its ambitions of increasing choice for people with learning disabilities and enabling them to live independent lives within the community (DH 2001, 2006, 2007a, 2007b, 2009). Over the last decade, the proportion of people with learning disabilities whose choices were restricted to a long stay in a hospital bed has nearly halved (Glover \& Olson 2012, NHS England 2015a). However, in 2012 the BBC broadcast a programme on Winterbourne View care home for adults with learning disabilities which provided evidence of routine mistreatment and abuse of vulnerable adults which was not identified through compliance procedures or regulatory inspection visits ( $\mathrm{DH} 2012)$. A series of national reviews have taken place subsequently, including the Winterbourne View Joint Improvement Programme, and following the homes closure (LGA 2015) the Transforming Care programme (NHS England 2014, 2015b). The ambition for the national programmes is to improve the lives of learning disabled people and/or people with autism whose behaviour challenges professionals and services through reducing inappropriate stays in hospital settings and increasing the extent to which people experience independence, inclusion in their community, and are able to make choices about how they want to live their lives (NHS England 2015b). Whilst the Transforming Care policy intent is targeted at people who were at high risk of an inpatient hospital admission, the associated national service model described in Building the Right Support is ambitious, describing a framework which aims to achieve better outcomes for the total population of people with learning disabilities and/or autism within local areas. However, despite the rhetoric of independence and choice in government policy towards adults with a learning disability, there is little evidence that a change is taking place to make the policy 
intent real through appropriate levels of resources being made available to secure more autonomous lives for those requiring support.

Whilst creating the conditions to enable people to live independently is a major milestone towards upholding people's Article 19 rights (EPRS 2016), the proposed national service model does not yet describe a comprehensive strategy towards achieving a paradigm shift from services taking for granted that their services are 'helpful' (Morgan 2012) towards services instead viewing their approach from the perspective of being there to safeguard and uphold a comprehensive programme of enforceable rights (EHRC 2014) as provided for by the UN Convention of the Rights of Persons with Disabilities (UK Enable 2015). Article 19 of the CRPD enshrines the right of persons with learning disabilities to live fully inclusive lives, enabled through wide ranging community support and access to independent living. For social workers working in the field of learning disabilities social work, whose professional practice identity is defined through being grounded in human rights (BASW 2014), the drive towards desinsitutionalisation has had a major impact on practice over the last three decades. Brokerage of support for people to live independent and fulfilling lives, accessing the full range of their rights as UK citizens, has become a major focus of learning disabilities social work practice.

In 2016, the Department of Health in England announced in the newly published vision for adult social work (DH 2016) the intention to pilot the role of a Named Social Worker in the field of learning disability social work. There are 6 pilot sites where social workers are piloting the role, including Camden, Nottingham, Sheffield, Liverpool, Hertfordshire and Calderdale. In Hertfordshire and Calderdale, the approach being advocated for is one grounded in human rights and citizenship in keeping with the global definition of good social work practice (BASW 2014). The 
focus on the human aspect of social work reflects the observations of Goodley \& Runswick-Cole (2014) that learning disabled people's voices, independence, politics and capacity for self-advocacy has been systematically dehumanised by society. The limited access to community experiences, social networks and choice-making opportunities (Emerson et al 2014) which people with a learning disability experience, continues to impact significantly on their health and well-being (Hatton el al 2016).

It over 50 years since, Erving Goffman proposed a definition for a total institution in his seminal book Asylums. Goffman observed such "closed world" settings featured breakdowns of the distinctions which would usually exist between play, work and sleep so that all happened under a single authority within a single setting. In the total institution people would live depersonalised lives following rigid institutional routines which helped maintain social distance between the staff in the setting and the person. Whilst in the UK deinstitutionalisation has led to the asylums being decommissioned and significantly more people living in community settings, the mindset of the total institution is pervasive and has followed people into their new homes manifesting as restrictive institutionalised routines which continue to limit their life experience (Hatton et al 1996, Emerson \& Hatton 1994). The emergence of selfadvocacy groups such as Stay up Late Campaign (2012) is a reaction against the intransigence of the institutionalised, infantilizing mindsets which lead to routinised meal times and bed times.

Inspired by the Stay up Late Campaign, in 2015 two social work teams who were supporting people to live more independent lives set out to find out whether routinised care and support on an evening was the experience of the people they were supporting. Specifically they set out to ask what was happening in community home settings for people with a learning disability at $8 \mathrm{pm}$ on an evening. This paper reports on the findings from the evaluation. 
The service evaluation followed National Research Ethics guidelines and the design took account of the Joint University Council Social Work Education Committee code of practice for research ethical and moral guidance (JUC 2016). Participant consent was secured from all participants who were invited to contribute to the study. Information about the study was provided in Easy Read format for those who requested it. It was made clear in the consent literature that people did not have to participate if they chose not to do so. Social workers who were also qualified as Best Interest Assessors were involved in the design and implementation of the evaluation to ensure that the rights of people with learning disabilities who may have lacked capacity to consent to participate were upheld. The initial analysis was shared with people who participated in the study during a focus group session to support the process of making sense of the findings.

The evaluation was conducted as a form of practitioner-led research in action. Practitioner-led research aims to integrate knowledge generation with actions and experience which will generate recommendation to further improve practice (Heron \& Reason 2001, Shaw, Lunt \& Mitchell 2014). It is particularly relevant for service evaluations involving social workers where critical participatory action research traditions are coherent with cultural conventions (Kemmis 2008).

\section{Methods}

\section{Design}

Four evaluation visits were conducted, two in each Local Authority. The settings were purposefully sampled from across a range of community based accommodation settings for adults with learning disabilities. including supported independent tenancies, supported living and CQC registered residential care homes 
and residential with nursing care homes. The demographic characteristics of individual participants was not collected during the audit, statistical analyses were therefore conducted as independent variable tests.

Two unannounced evaluation visits took place in each Local Authority area, repeated 6 months apart to provide results for comparison at different times of the year. The visits were unannounced to reduce the risk of the Hawthorne effect (Adair 1984) resulting in behaviours changing within the settings as a result of the evaluation taking place. Evaluation teams of qualified social workers from the Learning Disability Social Work services in both LA1 and LA2, visited each of the settings wearing their ID Badges with a covering letter from the Director of Adult Social Services explaining their role and the purpose of the evaluation. In total 112 social workers took part in the evaluation visits working in teams of two. Each pair visited up to two settings on the night of each audit. The evaluation visits in LA1 took place between 2000-2100 hours on one Friday evening in March and October 2015. The evaluation visits in LA2 took place between $2000-2100$ hours on one Thursday evening in January and June 2015. These four visits provided data which covered different points of the calendar year, providing insight about the extent to which people were independently choosing how they structured their evening or whether they were subject to institutional routines.

\section{Procedure}

In LA1, 33 settings owned by 12 care providers were visited during the Time 1 visit, providing accommodation for 160 people, of which 135 participated in the evaluation. Twenty-nine of these settings were revisited during the Time 2 visit six months later providing accommodation for 143 people of which 127 took part in the evaluation. Three settings had been decommissioned since the first visit and were no longer providing accommodation for adults with learning disabilities and a further unit was in the process of being decommissioned. The evaluation teams in LA1 each visited 
two settings, the first visit taking place at $2000 \mathrm{hrs}$ and the second $2030 \mathrm{hrs}$ on a Friday evening.

In LA2, 23 settings owned by 18 care providers were visited during the $T 1$ visit providing accommodation for 136 people, all of whom participated in the evaluation. Fourteen of the settings evaluated in LA2 were re-visited six months later during the T 2 visit. An additional two settings providing accommodation for 16 people were also visited which had not previously been evaluated. One of these additional settings was run by a care provider where the evaluation team had found $90 \%$ of residents were 'ready for bed' during their $\mathrm{T} 1$ visit. The settings visited during the $\mathrm{T}$ 2 visit provided accommodation for 110 people, all of whom participated. Fewer settings were visited the second evaluation due to reduced availability of social workers to contribute to the data collection process. The evaluation teams visited all settings in LA2 at 2030hrs on a Thursday evening.

Data was categorised and coded by the social work managers organising the evaluation. The categories were: gone out; up and not ready for bed; up and ready for bed; in bed awake; and in bed asleep. In addition, the social workers recorded the hour in which the person had eaten their evening meal. The social workers in LA1 and LA2 also recorded in field notes free text any comments given by staff in the settings where they volunteered an explanation as to why people were in bed at the time of the visit.

An evaluation tool ${ }^{1}$ was used in all four visits to improve the rigour of data collection procedures. To address concerns that the evaluation would by nature provide a limited snap shot in time, data collection was repeated in each Local Authority six months after the original visit. The purpose of the $T 2$ visit was to validate the $T 1$ observations and enable comparisons to be made between the findings.

\footnotetext{
${ }^{1}$ The evaluation tool is available on request from the authors
} 


\section{Materials}

The evaluation tool was developed by social workers involved. It was designed to capture data in relation to meal times, evening routines and free text commentary, where offered, about the reasons why people were in bed if this was found to be the case. The same evaluation tool was used in all four visits conducted in both LA1 and LA2. The social workers completed the evaluation tool during the visit which captured information about meal times and where people were at the time of the visit.

\section{Analysis}

Faced with the volume of data generated, the approach towards systematic analysis and interpretation (Robson 2011) of data was framed using a set of rules (Silverman 2011). These rules emphasised getting stuck into the analysis from an early stage, allowing the narrative to emerge from the data rather than trying to leap to early hypotheses, and being thorough and true to the data throughout the process to improve the validity of the analysis and findings.

From the outset analytical choices were made in relation to data management, with a view towards achieving reliability through use of low-inference descriptors (Seale 1999). The Evaluation Team in LA1 captured field notes providing descriptions of what choices had been made about people's bed time routines in the language of the person living in the settings or the staff working there (Silverman 2011).

In LA1, data was uploaded by the team who had collected it to a Share Point site from which it was extracted and analysed using Microsoft Excel. In LA2 the data was manually inputted into Microsoft Excel for analysis. The statistical significance was calculated using independent samples tests - Fisher's Exact Test and ChiSquare analysis. 
Secondary data was collected through a search performed on the Care Quality Commission (CQC) web site for the most recently published CQC ratings and reports on outcomes from inspection. In LA1 an additional search was conducted on the proprietary management information system which recorded adult safeguarding alerts and requests for authorisation under Deprivation of Liberty Safeguards.

\section{Findings}

The evaluation involved visits to 56 settings managed by 28 care provider organisations across both Local Authorities. Two of the provider organisations were found to be operating in both Local Authorities. The settings provided accommodation for up to 313 people (range $1-16$ ), with an average of 5 people living in each setting. Most (89\%) of people living in the settings chose to participate, with 507 contacts made during the four evaluation visits.

Twenty of the settings visited were classified by the Care Quality Commission (CQC) as regulated supported living settings (CQC 2015a). Seven care agencies managed these settings. At the time of the evaluation, nearly three quarters $(71 \%)$ were rated as 'good' in their most recent inspection report. One of the providers was rated as 'requiring improvement'. One provider's rating changed during a CQC routine inspection which took place between T 1 and T 2 from 'good' to 'requires improvement'.

Four of the settings in LA1 visited during the evaluation were classified by the evaluation team as 'supported accommodation'. People living in these settings were sustaining an independent tenancy with personal assistance.

Thirty of the settings visited were registered with the CQC for provision of residential care, six of which were also registered for residential with nursing care. There were 207 people living in these settings who participated. At the time of the evaluation, 
$94 \%$ of the settings registered with CQC for residential care were rated as meeting all care standards (CQC 2015b) in their most recent inspection reports.

Table 1 about here

Across all four visits, $69 \%$ of adults with learning disabilities who participated in the evaluation were engaged in some form of bed time related routine by $2030 \mathrm{hrs}$ on an evening. Nearly three quarters (73\%) of those who were observed to be ready for bed at the time of the visit had eaten their evening meal between $1700-1800 \mathrm{hrs}$. Applying Fisher's exact test, at $\mathrm{T} 1$ there was a strong association $(\mathrm{p}=0.0001)$ between the early evening meal time and the person being ready for or in bed by 2030hrs. At T 2 an earlier meal time was not as strongly associated $(p=0.051)$ with being ready for or in bed by $2030 \mathrm{hrs}$. The results across both times were that if the person had an early meal, they were relatively unlikely to be up and not ready for bed by $2030 \mathrm{hrs}$ ( $24.1 \%$ of people who had an early meal at $\mathrm{T} 1 ; 29.0 \%$ of people who had an early meal at T 2). However, people who had a later meal possibly became less likely to be up and not ready for bed by $2030 \mathrm{hrs}$ from T $1=59.0 \%$; T 2 $=42.6 \%$.

The evaluation found across all four visits that $7 \%$ of people had gone out, $24 \%$ were up but not ready for bed, $34 \%$ were up and ready for bed, $19 \%$ were in bed awake and $15 \%$ were in bed asleep (see Table 2 for details).

Table 2 about here

There were significant differences $($ Chi-square $=38.66, \mathrm{df}=3, \mathrm{p}<0.001)$ observed in the proportion of people who were up and those who were ready for bed or in bed between the different types of accommodation setting (see Table 3). People living independently through a supported tenancy agreement were 1.75 times more likely to be up and not ready for bed, and 4.5 times more likely to have gone out for the evening than people living in any other setting. People living in residential with 
nursing care were 1.8 times more likely to be in bed at the time of the evaluation visit.

Table 3 about here

The evaluation visits in LA1 also captured free text commentary from staff working in the settings managed by care providers. Narrative accounts of why people were found to be ready for bed were recorded from 32 care provider staff during $T 1$ and 37 provider staff during T 2. At T 1 nearly half (43\%) of the narrative accounts were framed as being the person's choice. At T $289 \%$ of the narrative accounts presented the decision to go to bed as a positive choice on the part of the person with learning disabilities.

\section{Discussion}

The findings indicate that whilst significant progress has been made in implementing a service model in the UK which encourages independence through choice of accommodation, new forms of controls have replaced the old institutional ones (Emerson \& Hatton 2006). Despite over 20 years of public policy interventions designed to reduce health inequalities and improve the quality of the lives led by people with learning disabilities, institutional routines were found to continue to be a pervasive feature. People with a learning disability living in the settings visited during the big bed time audit were experiencing lives defined by meal and bed time routines. There were, however, significant differences observed between the types of accommodation setting which suggest that the more independent the service model defining the environment, the more likely it would be that the setting operated in a way that promoted self-governance and autonomy (O'Shea 2012).

The dehumanising impact of staff in the settings using operating routines to manage the lives of the people with learning disabilities living there is illustrated in the artefact 
which the evaluation team found pinned to the chair of a person living in one of the settings visited:

\section{'Dinner 5pm; Bedtime 6pm; With Medication; Night Night; Sweet Dreams'}

In another setting the evaluation team found that there was only a single worker, in contravention of the person's care plan. The plan identified the need for double staffing support, when questioned by the evaluation team the staff reported that the person was 'padded up in case of incident'. In a setting accommodating 12 male residents staff were found to be sat together watching Coronation Street. None of the residents were watching the programme, they told the evaluation team that they must not disturb the staff as 'staff are busy, staff have jobs to do'. People largely perceive themselves and others in relative terms, drawing reference from the value they attribute to others. The observations recorded during the visits should be contextualised within the limitations of the study including the decision taken at the design stage not to collect data on the demographic characteristics of participants which may have generated deeper insights into the patterns observed However, the findings suggest that further research into the cultural conventions which exist within supported accommodation settings could add value to the Transforming Care approach as the new service model is implemented across the UK.

A recurrent theme within the responses given by staff working in settings where people were found to be ready for bed at the time of the evaluation visit was to positively frame that people were exercising 'choice'. Whilst it is possible to argue that people who were found to be ready for bed were understanding, reasoning and exercising control, significant differences were observed between the types of setting which indicate that there are more complex contextual factors influencing decision making about bed times. As shown in Table 3, people were found to be ready for bed during the evaluation in all settings which were managed by a care provider. The 
largest proportion of people who at the time of the evaluation were found to have plans for the evening were living in accommodation which met the definition of a supported tenancy setting.

\section{Limitations}

The study was small scale, whilst the approach determined was to ensure practice in conducting the evaluation was in keeping with ESRC and JUC principles, the size of the sample by nature amplified issues which were of particular importance within the sample. It is problematic to generalise the findings to the experiences of adults with learning disabilities living in other types of supported accommodation or to extrapolate the findings to a bigger, regional or national picture.

Due to practicalities there are limitations with the controls including the audit was conducted on a Friday in LA1 and a Thursday in LA2 and the evaluation tool was not able to be used in all settings in LA2 during the first evaluation and had to be completed retrospectively. Data collected in LA2 was manually inputted into Microsoft Excel for analysis. This resulted in some data being lost, it also led to some issues with data quality. It is not possible to verify if the same individuals participated in the audit between $\mathrm{T}$ 1 and $\mathrm{T} 2$ which meant that the analysis had to be conducted as independent variable tests and statistical comparisons could not be made between the times.Conclusion and Implications for Practice

The findings from the social worker visits were that institutional routines are a pervasive feature, which infantilize and restrict the extent to which adults with a learning disability experience their rights (O'Shea 2012). Evening routines described in this paper are as a proxy for a wider test of how people experience citizenship and the ordinary lives which their non-learning disabled peers experience. There are 
implications in the findings for commissioning practices, social work support planning and social work education. The global definition of social work emphasises the role of social workers in upholding social justice (BASW 2014). As the lead professional in arranging and planning support for learning disabled people, greater attention needs to be paid to the culture of the care provider. Social work practice focused on building people's efficacy as self-advocates could make a significant impact on care providers culture, practice and ultimately quality.

\section{Funding}

This is an independent paper which reflects the views of the authors only.

\section{Acknowledgements}

The authors wish to note thanks to the people whose homes were visited and who consented to participate. The authors wish to thank Professor Chris Hatton, Lancaster University, for his kind words and support with the earlier drafts of this paper.

\section{References}

Adair, J G (1984). The Hawthorne Effect: A reconsideration of the methodological artefact. Journal of Applied Psychology. 69 (2) 334-345.

British Association of Social Workers (2014). Global Definition of Social Work. [Online]. https://www.basw.co.uk/resource/?id=3293

Care Quality Commission (2015a). Supported Living Schemes: Regulated activities for which the provider may need to register - Guidance for providers. [Online]. http://www.cqc.org.uk/sites/default/files/documents/rp poc1c 10083220110210 v1 00 ras a supported living scheme needs to register for for publication.pdf. 
Care Quality Commission (2015b). Guidance for providers on meeting the fundamental standards and on CQC's enforcement power. [Online].

http://www.cac.org.uk/sites/default/files/20140725 fundamental standards and enf orcement consultation final.pdf.

Council of Europe (2010). European Convention on Human Rights. [Online]. http://www.echr.coe.int/Documents/Convention ENG.pdf.

Department of Health (2001). Valuing People: A New Strategy for Learning disabilities for the $21^{\text {st }}$ Century. [Online].

https://www.gov.uk/government/uploads/system/uploads/attachment data/file/25087 7/5086.pdf.

Department of Health (2006). Our Health, Our Care, Our Say: A New Direction for Community Services. London. HMSO. [Online].

https://www.gov.uk/government/uploads/system/uploads/attachment data/file/27223 8/6737.pdf.

Department of Health (2007a). Valuing People Now: From Progress to Transformation - A consultation on the next three years of learning disabilities policy. London. HMSO. [Online].

http://webarchive.nationalarchives.gov.uk/+/www.dh.gov.uk/en/consultations/livecons ultations/dh 081014.

Department of Health (2007b). Putting People First: a Shared Vision and Commitment to the Transformation of Adult Social Care. London. HMSO. [Online]. http://webarchive.nationalarchives.gov.uk/20130107105354/http:/www.dh.gov.uk/pro $\underline{\mathrm{d} \text { consum dh/groups/dh digitalassets/@dh/@en/documents/digitalasset/dh } 081119}$ pdf.

Department of Health (2009). Valuing People Now: A new three-year strategy for people with learning disabilities - making it happen for everyone. MHSO. [Online]. 
http://webarchive.nationalarchives.gov.uk/20130107105354/http:/www.dh.gov.uk/pro

$\underline{\mathrm{d} \text { consum } \mathrm{dh} / \mathrm{groups} / \mathrm{dh} \text { digitalassets/documents/digitalasset/dh 093375.pdf }}$

Department of Health (2012). Transforming Care: A National Response to

Winterbourne View Hospital. London. HMSO. [Online].

https://www.gov.uk/government/uploads/system/uploads/attachment data/file/12731

$\underline{\text { 0/final-report.pdf.pdf. }}$

Department of Health (2014a). The Care Act. London. HMSO. [Online].

http://www.legislation.gov.uk/ukpga/2014/23/contents/enacted

Department of Health (2016). Vision for Adult Social Work. [Online].

https://www.gov.uk/government/publications/vision-for-adult-social-work-in-england

Economic \& Social Research Council (2015). ESRC Framework for Research Ethics:

Updated January 2015. [Online]. http://www.esrc.ac.uk/files/funding/guidance-for-

applicants/esrc-framework-for-research-ethics-2015/.

Emerson, E \& Hatton, C (1994). Moving Out: Impact of Relocation from Hospital to

Community on the Quality of Life of People with Learning disabilities. HMSO.

London.

Emerson, E \& Hatton, C (2006). 'Impact of Deinstitutionalisation on Service Users in UK'. In J Mansell \& K Ericsson (Eds). Deinstitutionalisation and Community Living Learning disabilities services in Scandinavia, Britain and the USA. Chapman \& Hall. London.

Emerson, E, Hatton, C, Roberston, J \& Baines, S (2010). Perceptions of Neighbourhood Quality, Social and Civic Participation and the Self Rated Health of British Adults with Learning disabilities: Cross Sectional Study. BMC Public Health. 14 (1) 1252, 09.12.2014. 
Equality \& Human Rights Commission (2014). Monitoring the Implementation of the UN Convention on the Rights of Persons with Disabilities. [Online].

https://www.equalityhumanrights.com/sites/default/files/monitoring the implementati on of the uncrpd2.pdf

European Parliamentary Research Service (2016). EU Implementation of the UN Convention on the Rights of Persons with Disabilities. [Online].

http://www.europarl.europa.eu/RegData/etudes/IDAN/2016/536347/EPRS IDA(2016 $\lcm{536347 \text { EN.pdf }}$

Freire, P (1972). Pedagogy of the Oppressed. London. Penguin Books

Glover, G \& Olson, V (2012). Assessment and Treatment Settings and Other Specialist Inpatient Care for People with Learning disabilities in the Count-Me-In surveys, 2006 to 2010. [Online].

http://www.improvinghealthandlives.org.uk/uploads/doc/vid 17542 IHAL\%20201209\%20A\&T\%20and\%20other\%20specialist\%20inpatient\%20care\%20for\%20people \%20with\%20LD\%20in\%20the\%20Count-Me-In\%20Census.pdf

Goffman, I (1961). Asylums: Essays on the Social Situation of Mental Patients and Other Inmates. Penguin Social Sciences.

Goodley, D \& Runswick-Cole, K (2014). Becoming dis/human: Thinking about the human through disability. Discourse: Studies in the Cultural Politics of Education. DOI: 10.1080/01596306.2014.930021

Gray, D E (2004). Doing Research in the Real World. Second Edition 2009. London. SAGE Publications Limited.

Hatton, C, Emerson, E, Robertson, J, Henderson, D, \& Cooper, J (1996). Factors Associated with Staff Support and User Lifestyle in Services for People with Multiple- 
Disabilities: A Path Analytic Approach. Journal of Learning disabilities Research. $\mathbf{4 0}$ (5) 466-477.

Hatton C., Glover G., Emerson E., \& Brown I. (2016) People with Learning

Disabilities in England 2015. Public Health England, London.

Heron, J \& Reason, P (2001). 'The Practice of Cooperative Inquiry: Research "with" rather than "on” people'. In P Reason \& H Bradbury-Huang (Eds). Handbook of Action Research: Participative Inquiry and Practice. Second Edition. London. SAGE Publications Limited.

Hirschman, A O (1970). Exit, Voice, and Loyalty: Responses to Decline in Firms, Organisations, and States. Cambridge, Massachusetts. Harvard University Press.

Joint University Council (2016). Social Work Education Committee Code of Ethics for Social Work and Social Care Research. [Online]. http://www.juc.ac.uk/swec-

\section{research-code.html}

Kemmis, S (2008). 'Critical Theory and Participatory Action Research'. In P Reason

\& H Bradbury (Eds). Handbook of Action Research: Participative Inquiry and Practice. London. SAGE Publications Limited.

Linstead, S \& Grafton-Small, R (1992). On Reading Organisational Culture.

Organisational Studies. 13 (3) 331-335.

Local Government Association (2015). A Place I Call Home. [Online].

http://www.local.gov.uk/place-i-call-home.

Mansell, J (2010). Raising our Sights: Services for Adults with Profound Learning and Multiple Disabilities. Tizard Learning Disabilities Review. 15 (3) 5-12.

Morgan, H. (2012). The Social Model of Disability as a Threshold Concept:

Troublesome Knowledge and Liminal Spaces in Social Work Education. Social Work Education. 31 (2) 215-226. 
NHS England (2014). Winterbourne View: Time for Change: Transforming the Commissioning of Services for People with Learning disabilities and/or Autism. [Online]. http://www.england.nhs.uk/wp-content/uploads/2014/11/transformingcommissioning-services.pdf

NHS England (2015a). Transforming Care. [Online].

http://www.england.nhs.uk/ourwork/qual-clin-lead//d/transform-care/.

NHS England (2015b). Building the Right Support: A National Plan to Develop Community Services and Close Inpatient Facilities for People with a Learning disabilities and/or Autism who Display Behaviour that Challenges, including those with a Mental Health Condition. [Online]. https://www.england.nhs.uk/wpcontent/uploads/2015/10/ld-nat-imp-plan-oct15.pdf.

NHS England (2015c). Supporting People with a Learning disabilities and/or Autism who display Behaviour that Challenges, including those with a Mental Health Condition: Service Model for Commissioners of Health and Social Care Services. [Online]. https://www.england.nhs.uk/wp-content/uploads/2015/10/service-model291015.pdf.

O'Shea, T (2012). Autonomy and Value. [Online]. http://autonomy.essex.ac.uk/wpcontent/uploads/2011/05/Autonomy-and-Value-GPR-June-2012.pdf

P \& Q v Surrey County Council [2011] EWCA Civ 190. [Online]. http://www.mentalhealthlaw.co.uk/Re $P$ and $Q ; P$ and $Q \vee$ Surrey County Coun cil; sub nom Re MIG and MEG (2011) EWCA Civ 190

P V Cheshire West (2014) UKSC 19, (2014), MHLO 16. [Online]. http://www.mentalhealthlaw.co.uk/Cheshire West and Chester Council v P (2014 LUKSC 19, (2014) MHLO 16 
Robson, C (2011). Real World Research. Third Edition. John Wiley and Sons Ltd. West Sussex.

Shaw, I, Lunt, N \& Mitchell, F (2014). Practitioner Research in Social Care: A Review and Recommendations. National Institute for Health Research. London.

Silverman, D (2010). Doing Qualitative Research. Reprint 2013. Fourth Edition. London. SAGE Publications Limited.

Silverman, D (2011). Interpreting Qualitative Data. Reprint 2014. Fourth Edition. London. SAGE Publications Limited.

Stay up Late (2012). [Online]. http://stayuplate.org/

UN Enable (2015). UN Convention on the Rights of Persons with Disabilities http://www.un.org/disabilities/default.asp?id=279. 


\section{Tables}

Table 1: Summary of the Characteristics of the settings visited during evaluation visits

\begin{tabular}{|c|c|c|c|c|c|c|c|c|}
\hline & $\begin{array}{l}\text { Supp } \\
\text { Ten }\end{array}$ & $\begin{array}{l}\text { irted } \\
\text { ncy }\end{array}$ & $\begin{array}{r}\text { Supp } \\
\text { Lir }\end{array}$ & $\begin{array}{l}\text { rted } \\
\text { ig }\end{array}$ & \multicolumn{2}{|c|}{$\begin{array}{l}\text { CQC } \\
\text { Registered } \\
\text { Residential } \\
\text { Care Home }\end{array}$} & \multicolumn{2}{|c|}{$\begin{array}{l}\text { CQC } \\
\text { Registered } \\
\text { Residential } \\
\text { with Nursing } \\
\text { Care Home }\end{array}$} \\
\hline & $\begin{array}{c}N \\
\text { Setting } \\
\mathrm{s}\end{array}$ & $\begin{array}{c}N \\
\text { Peopl } \\
\mathrm{e} \\
\text { living } \\
\text { in the } \\
\text { unit }\end{array}$ & $\begin{array}{c}N \\
\text { Setting } \\
\mathrm{s}\end{array}$ & $\begin{array}{c}N \\
\text { Peopl } \\
\mathrm{e} \\
\text { living } \\
\text { in the } \\
\text { unit }\end{array}$ & $\begin{array}{c}N \\
\text { Setting } \\
\mathrm{s}\end{array}$ & $\begin{array}{c}N \\
\text { Peopl } \\
\mathrm{e} \\
\text { living } \\
\text { in the } \\
\text { unit }\end{array}$ & $\begin{array}{c}N \\
\text { Setting } \\
\mathrm{s}\end{array}$ & $\begin{array}{c}N \\
\text { Peopl } \\
\text { e } \\
\text { living } \\
\text { in the } \\
\text { unit }\end{array}$ \\
\hline $\begin{array}{l}\text { LA1 } \\
\text { Evalu } \\
\text { ation } \\
1\end{array}$ & 4 & 14 & 23 & 91 & 5 & 39 & 2 & 16 \\
\hline $\begin{array}{l}\text { LA2 } \\
\text { Evalu } \\
\text { ation } \\
1\end{array}$ & & & & - & 17 & 113 & 4 & 23 \\
\hline $\begin{array}{l}\text { LA1 } \\
\text { Evalu }\end{array}$ & 4 & 17 & 18 & 71 & 5 & 40 & 2 & 15 \\
\hline
\end{tabular}




\begin{tabular}{|l|l|l|l|l|l|l|l|l|}
\hline ation & & & & & & & \\
\hline LA2 & - & - & - & - & 13 & 94 & 3 & 16 \\
Evalu & & & & & & & & \\
ation & & & & & & & & \\
\hline 2
\end{tabular}


Table 2: Summary of results from each the four evaluations conducted

\begin{tabular}{|c|c|c|c|c|c|c|c|}
\hline & $\begin{array}{c}N \\
\text { people } \\
\text { living in } \\
\text { the } \\
\text { settings }\end{array}$ & $\begin{array}{c}N \\
\text { people } \\
\text { particip } \\
\text { ating in } \\
\text { the } \\
\text { evaluati } \\
\text { on }\end{array}$ & $\begin{array}{c}\% \text { Gone } \\
\text { Out }\end{array}$ & $\begin{array}{c}\text { \% Up \& } \\
\text { Not } \\
\text { Ready } \\
\text { for Bed }\end{array}$ & $\begin{array}{l}\text { \% Up \& } \\
\text { Ready } \\
\text { for Bed }\end{array}$ & $\begin{array}{c}\% \text { In } \\
\text { Bed } \\
\text { Awake }\end{array}$ & $\begin{array}{c}\% \text { In } \\
\text { Bed } \\
\text { Asleep }\end{array}$ \\
\hline $\begin{array}{l}\text { LA1 } \\
\text { Evaluation } 1\end{array}$ & 160 & 135 & 16 & 24 & 31 & 15 & 14 \\
\hline $\begin{array}{l}\text { LA2 } \\
\text { Evaluation } 1\end{array}$ & 136 & 134 & - & 20 & 43 & 21 & 17 \\
\hline $\begin{array}{l}\text { LA1 } \\
\text { Evaluation } 2\end{array}$ & 143 & 127 & 8 & 39 & 23 & 19 & 11 \\
\hline $\begin{array}{l}\text { LA2 } \\
\text { Evaluation } 2\end{array}$ & 120 & 110 & - & 22 & 44 & 16 & 18 \\
\hline
\end{tabular}


Table 3: Summary of results by community based accommodation type

\begin{tabular}{|c|c|c|c|c|c|c|}
\hline $\begin{array}{l}\text { Provider } \\
\text { Type }\end{array}$ & $\begin{array}{c}N \\
\text { People }\end{array}$ & $\begin{array}{c}\% \text { Gone } \\
\text { Out }\end{array}$ & $\begin{array}{c}\text { \% Up \& Not } \\
\text { Ready for } \\
\text { Bed }\end{array}$ & $\begin{array}{c}\% \text { Up \& } \\
\text { Ready for } \\
\text { Bed }\end{array}$ & $\begin{array}{c}\text { \% In Bed } \\
\text { Awake }\end{array}$ & $\begin{array}{c}\% \text { In Bed } \\
\text { Asleep }\end{array}$ \\
\hline $\begin{array}{l}\text { Supported } \\
\text { Tenancy }\end{array}$ & 19 & 32 & 42 & 16 & - & 11 \\
\hline $\begin{array}{l}\text { Supported } \\
\text { Living }\end{array}$ & 132 & 13 & 29 & 30 & 17 & 11 \\
\hline $\begin{array}{l}\text { Residential } \\
\text { Care Home }\end{array}$ & 289 & 5 & 24 & 39 & 18 & 14 \\
\hline $\begin{array}{l}\text { Residential } \\
\text { with } \\
\text { Nursing } \\
\text { Care Home }\end{array}$ & 67 & - & 9 & 28 & 34 & 28 \\
\hline
\end{tabular}

